\title{
$\mathrm{Gd}-\mathrm{Ba}-\mathrm{Cu}-\mathrm{O}$ 系バルク超伝導材料の機械的特性および 捕捉磁場特性に及ぼす銀添加の影響
}

\author{
成木紳也坂井直道松井元英村上雅人
}

財団法人 国際超電導産業技術研究センター超電導工学研究所

\author{
J. Japan Inst. Metals, Vol. 66, No. 4 (2002), pp. 309-314 \\ Special Issue on Advances in Superconducting Materials \\ (C) 2002 The Japan Institute of Metals
}

\section{Effect of Silver Addition on the Mechanical and Field Trapping Properties of Gd-Ba-Cu-O Bulk Superconductors}

Shinya Nariki, Naomichi Sakai, Motohide Matsui and Masato Murakami

Superconductivity Research Laboratory, International Superconductivity Technology Center, Tokyo 105-0023

The effect of $\mathrm{Ag}$ addition on the microstructure and the mechanical and field trapping properties of $\mathrm{Gd}-\mathrm{Ba}-\mathrm{Cu}-\mathrm{O}$ bulk superconductor has been investigated. The single grain $\mathrm{Gd}-\mathrm{Ba}-\mathrm{Cu}-\mathrm{O}$ bulk superconductors $32 \mathrm{~mm}$ in diameter were fabricated with $0-$ 30 mass $\% \mathrm{Ag}_{2} \mathrm{O}$ additions by the melt growth method under controlled oxygen partial pressure of $1.0 \%$. From microscopic observations, it was found that the macro-cracks in the $a-b$ plane decreased with Ag addition. The three-point bending test showed that the average strength of $\mathrm{Ag}$-free bulk was $69 \mathrm{MPa}$ at room temperature, while the strength was dramatically improved to 110-115 MPa with 10-30 mass\% $\mathrm{Ag}_{2} \mathrm{O}$ additions. The trapped magnetic field of $\mathrm{Ag}$-free bulk sample was $1.3 \mathrm{~T}$ at $77 \mathrm{~K}$. The trapped field of bulk $\mathrm{Gd}-\mathrm{Ba}-\mathrm{Cu}-\mathrm{O}$ samples with $10-20$ mass $\% \mathrm{Ag}_{2} \mathrm{O}$ exhibited high values of $1.8-2.0 \mathrm{~T}$ at $77 \mathrm{~K}$. However, the trapped field of the sample with 30 mass $\% \mathrm{Ag}_{2} \mathrm{O}$ addition was lowered to $1.1 \mathrm{~T}$ with decreasing the critical current density. The trapped field of $\mathrm{Ag}$-added sample did not deteriorate with thermal cycles. The trapped fields at lower temperatures were also measured for the $\mathrm{Ag}$-free and 20 mass $\% \mathrm{Ag}_{2} \mathrm{O}$ added bulk samples without reinforcement by the metal ring or resin. $\mathrm{The} \mathrm{Ag}-\mathrm{free}$ bulk exhibited the trapped field of $3.0 \mathrm{~T}$ at $65 \mathrm{~K}$, however, the bulk was fractured at lower temperature due to an electromagnetic force. On the other hand, the Ag-added bulk could trap the higher field of $6.7 \mathrm{~T}$ at $55 \mathrm{~K}$, thanks to the improvement in mechanical strength.

(Received October 23, 2001; Accepted January 24, 2002)

Keywords: superconductor, $\mathrm{GdBa}_{2} \mathrm{Cu}_{3} \mathrm{O}_{y}$, silver, melt-growth, mechanical property, three point bending strength, crack, trapped magnetic field, critical current density

\section{1. 緒言}

溶融法により作製された RE-Ba-Cu-O $(\mathrm{RE} ; \mathrm{Y}$ および希土 類元素)系バルク超伝導材料は，配向した $\mathrm{REBa}_{2} \mathrm{Cu}_{3} \mathrm{O}_{y}$ ( RE123) 超伝導マトリックス相の中に, $\mathrm{RE}_{2} \mathrm{BaCuO}_{5}$ (RE211) 常伝導相からなる粒子が微細分散した複合材料で ある. RE211 粒子がピン止め中心として働くことにより, 非常に強い磁場を捕捉することができることから，バルク体 を強力な擬似永久磁石として応用する試みが近年注目を集め ている.バルク体の捕捉磁場を向上させるには, 臨界電流密 度 $\left(J_{\mathrm{c}}\right)$ の向上とバルク体の大型化が有効である.

これまでバルク超伝導材料の研究の多くは $\mathrm{Y}-\mathrm{Ba}-\mathrm{Cu}-\mathrm{O}$ 系 を中心に行われてきたが, 捕捉磁場の大きさは液体窒素温度 $(77 \mathrm{~K})$ で $1 \mathrm{~T}$ 程度であり, 従来の永久磁石が発生する磁場 をやや超える程度の值にとどまっていた。しかしながら， Yoo ら ${ }^{1)}$ により，低酸素分圧下で作製した LRE123(LRE は $\mathrm{Nd}, \mathrm{Sm}, \mathrm{Gd}$ などの軽希土類元素)系材料が Y123 系よりも高 い臨界温度 $\left(T_{\mathrm{c}}\right)$ と $J_{\mathrm{c}}$ を示すことが発見されて以来, $\mathrm{Sm} 123$ 系，Nd123 系などの軽希土類系バルク材料が注目を集める
ようになった．特に，Sm123 系超伝導材料は $\mathrm{Ag}$ を添加し て機械的強度を改善することにより，配向制御された大型バ ルク体の作製が可能となり，その捕捉磁場の大きさは $77 \mathrm{~K}$ で $2.1 \mathrm{~T}$ に達している ${ }^{2,3)}$. また, 著者らは Gd123 系超伝導 材料に関して，バルク体中の Gd211 相を微細化することに よって $J_{\mathrm{c}}$ を大きく向上させ ${ }^{4,5)}$, 直径 $32 \sim 50 \mathrm{~mm}$ のバルク 体で 1.5〜2.6 T $(77 \mathrm{~K})$ の高い捕捉磁場が得られることを報 告した ${ }^{6-9)}$. Gd123 系バルク材料は空気中で作製しても比較 的高い特性のバルク体が得られる10-13)ことから実用上有望 な材料と考えられる.

このようにバルク超伝導材料を用いると，これまで超伝導 コイルを使った超伝導マグネットでしか得られなかったよう な強い磁場を簡便に発生することができ，広範な応用が期待 される.しかしながら，バルク超伝導材料はセラミックス材 料であるため機械的に脆い性質を有しており，実用化のため には機械的強度の改善が必要である．例えば，バルク体を液 体窒素温度よりも低い温度で着磁した場合， $J_{\mathrm{c}}$ の増大によ り，非常に強い磁場を捕捉させることが可能となるが，同時 にバルク体に生じるローレンツカによりバルク体自体が破壊 されてしまうことが報告されている3,14-18)。すなわち，バル 
ク体の超伝導特性の向上に伴い，バルク体が捕捉できる磁場 は $J_{\mathrm{c}}$ よりもむしろ機械的強度によって制限されるようにな ってきている．バルク体の機械的特性を改善する方法の一つ としては Ag の添加が有効であることが Y123 系などでよく 知られているが18-22)，Gd123 系材料に関して Ag 添加の影 響に関する詳しい検討は行われていない。本研究では Gd123 系バルク材料の微細組織, 機械的特性，捕捉磁場特 性に対する Ag 添加の影響を系統的に検討した結果について 報告する。

\section{2. 実 験 方 法}

\section{1 バルク体の作製}

Gd123 粉末, Gd211 粉末を 2 : 1 のモル比になるよう秤量 し，これに $\mathrm{Pt}$ 粉末を 0.5 mass\% 抢よび $\mathrm{Ag}_{2} \mathrm{O}$ 粉末を 0 〜 30 mass\%添加, 混合したものを出発原料とした。ここで, Gd123 粉末については市販の試薬を用い, Gd211 粉末につ いては $\mathrm{Gd}_{2} \mathrm{O}_{3}, \mathrm{BaO}_{2}, \mathrm{CuO}$ の混合粉末 (モル比 $1: 1: 1$ )を $1173 \mathrm{~K}$ で $8 \mathrm{~h}$ 仮焼して作製した粉末を用いた。混合粉約 $150 \mathrm{~g}$ を直径 $40 \mathrm{~mm}$ の金型に充填し，一軸プレスで予備成 形を行った後, $200 \mathrm{MPa}$ の圧力で $\mathrm{CIP}$ (静水圧プレス)成形 を行い，前駆体を作製した

前駆体を $1 \% \mathrm{O}_{2}$ を含む $\mathrm{Ar}$ ガス雾囲気に保った電気炉内に 設置後, $1373 \mathrm{~K}$ で $0.5 \mathrm{~h}$ 加熱し，Gd123 相を分解溶解させ た。温度を $1298 \mathrm{~K}$ に下げ，大きさ $3 \mathrm{~mm}$ 程度の $\mathrm{Nd} 123$ (001)系バルク種結晶を溶融した試料の上面に付着させた. 温度を $1253 \mathrm{~K}$ まで下げた後， $0.15 \sim 0.5 \mathrm{~K} / \mathrm{h}$ の速度で 1228 $\mathrm{K}$ まで徐冷し, 結晶成長を行った。徐冷の際，バルク体の 底面の温度が上面よりも温度が高くなるように $0.2 \mathrm{~K} / \mathrm{mm}$ の温度勾配をつけた. $\mathrm{Ag}_{2} \mathrm{O}$ が無添加の試料に関しては, Gd123 相の分解溶融温度が $\mathrm{Ag}$ 添加試料に比べて高いことか ら，1275〜 $1243 \mathrm{~K}$ の範囲で徐冷を行った．得られたバルク 体を管状炉内に設置し, 酸素気流中, 673〜 723 K の温度で 300 h，熱処理を行った.

\section{2. 微細組織観察, 機械的特性評価}

$\mathrm{Ag}$ 粒子の分布状態，クラック，ボイド等の観察を目的と して, 酸素アニール後のバルク体の $a-b$ 面に垂直な断面を研 磨後, 光学顕微鏡を用いて微細組織の観察を行った.
バルク体の機械的特性の評価として, 三点曲げ強度の測定 を行った、試験片として, 酸素アニール後のバルク体から幅 $4 \mathrm{~mm}$, 高さ $3 \mathrm{~mm}$, 長さ $25 \sim 30 \mathrm{~mm}$ の試料を, $a(b)$ 軸方向 が長手方向に, $c$ 軸方向が高さ方向となるように $6 \sim 8$ 本切 り出した. 試験片の角は $0.1 \sim 0.2 \mathrm{~mm}$ 面取りを行い, $3 \mu \mathrm{m}$ の研磨紙で表面を研磨した。曲げ試験は室温において，下部 支点間距離 $16 \mathrm{~mm}$, クロスヘッド速度 $0.5 \mathrm{~mm} / \mathrm{min}$ の条件 で， $c$ 軸方向に荷重をかけて行った.

\section{3 超伝導特性, 捕捉磁場特性の評価}

試料の $T_{\mathrm{c}}$ および $J_{\mathrm{c}}$ を評価するため, 酸素アニール後のバ ルク体について， Nd123 種結晶を付着させた部分から約 2 $\mathrm{mm}$ 下部の領域より, 大きさ $1.5 \mathrm{~mm} \times 1.5 \mathrm{~mm} \times 1.0 \mathrm{~mm}$ 程 度の試験片を切り出し, 超伝導量子干渉型磁束計 (SQUID) を用いて, 磁化率の温度依存性と $77 \mathrm{~K}$ に打けるヒステリシ スループを測定した。

捕捉磁場評価のため, $7 \mathrm{~T}$ の定常磁場下でバルク体を液体 窒素中に浸漬して磁場中冷却し, 外部磁場を除去した後, バ ルク体の上面をホール素子で走査することにより $77 \mathrm{~K} に お ~$ ける捕捉磁場分布を測定した．この際，ホール素子とバルク 体上面との距離はホール素子表面を被覆している樹脂の厚さ $(0.7 \mathrm{~mm})$ を含めて $1.2 \mathrm{~mm}$ とした.さらに, 一部のバルク 体については，捕捉磁場の温度依存性を測定した。この場 合，上面にホール素子を付着させたバルク体を冷凍機内に設 置し，10 T の定常磁場中で所定の温度にバルク体を冷却 後，外部磁場を除去し，捕捉磁場の值を記録した。

\section{3. 結果および考察}

\section{1 微細組織観察}

Fig. 1 に結晶成長後のバルク体上面の写真を示す．いずれ の試料も Nd123 種結晶を中心に結晶が成長し, 全体が単一 粒からなるバルク体となっていることが分かる. バルク体の 直径は約 $32 \mathrm{~mm}$ であった。 $\mathrm{Y}-\mathrm{Ba}-\mathrm{Cu}-\mathrm{O}$ 系あるいは $(\mathrm{Nd}$, $\mathrm{Eu}, \mathrm{Gd})-\mathrm{Ba}-\mathrm{Cu}-\mathrm{O}$ 系バルク体においては， $\mathrm{Ag}$ を多量に添 加した場合，バルク体表面に大きさ数 $\mathrm{mm}$ の $\mathrm{Ag}$ の凝集粒 子が析出することが報告されているが23,24), 本研究の場合 30 mass\%の $\mathrm{Ag}_{2} \mathrm{O}$ を添加した場合でも $\mathrm{Ag}$ の析出量は少な く, 大部分がバルク体内に分散していることが確認された.
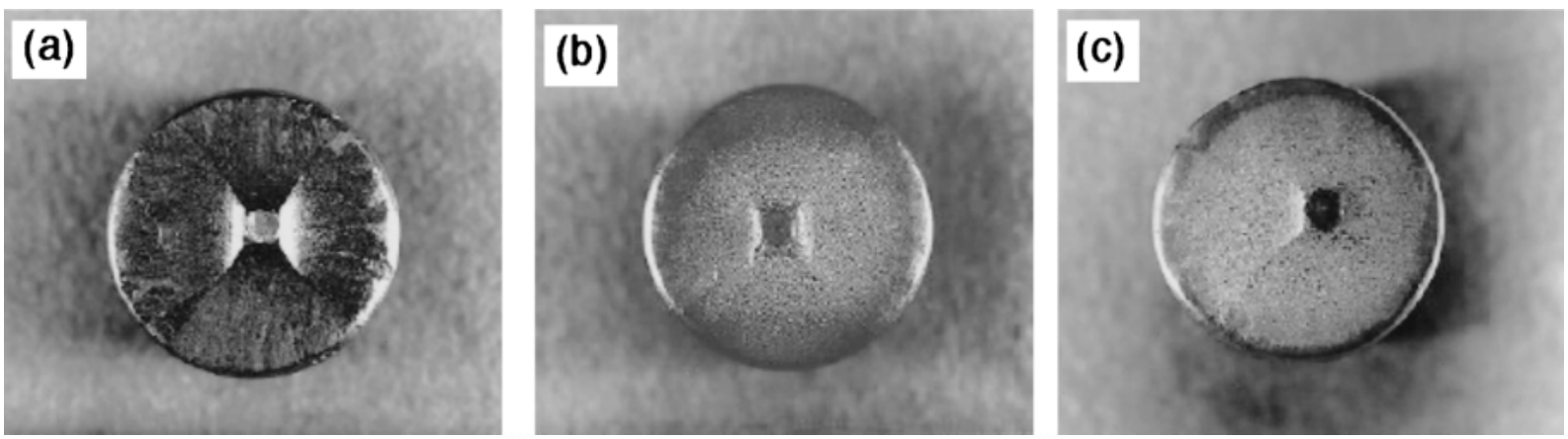

Fig. 1 Photographs of the top view of single-grain $\mathrm{Gd}-\mathrm{Ba}-\mathrm{Cu}-\mathrm{O} / \mathrm{Ag}$ bulk samples: (a) $\mathrm{Ag}$-free; (b) 10 mass $\% \mathrm{Ag}_{2} \mathrm{O}$; and (c) 30 mass $\% \mathrm{Ag}_{2} \mathrm{O}$. The diameter of each sample is $32 \mathrm{~mm}$. 

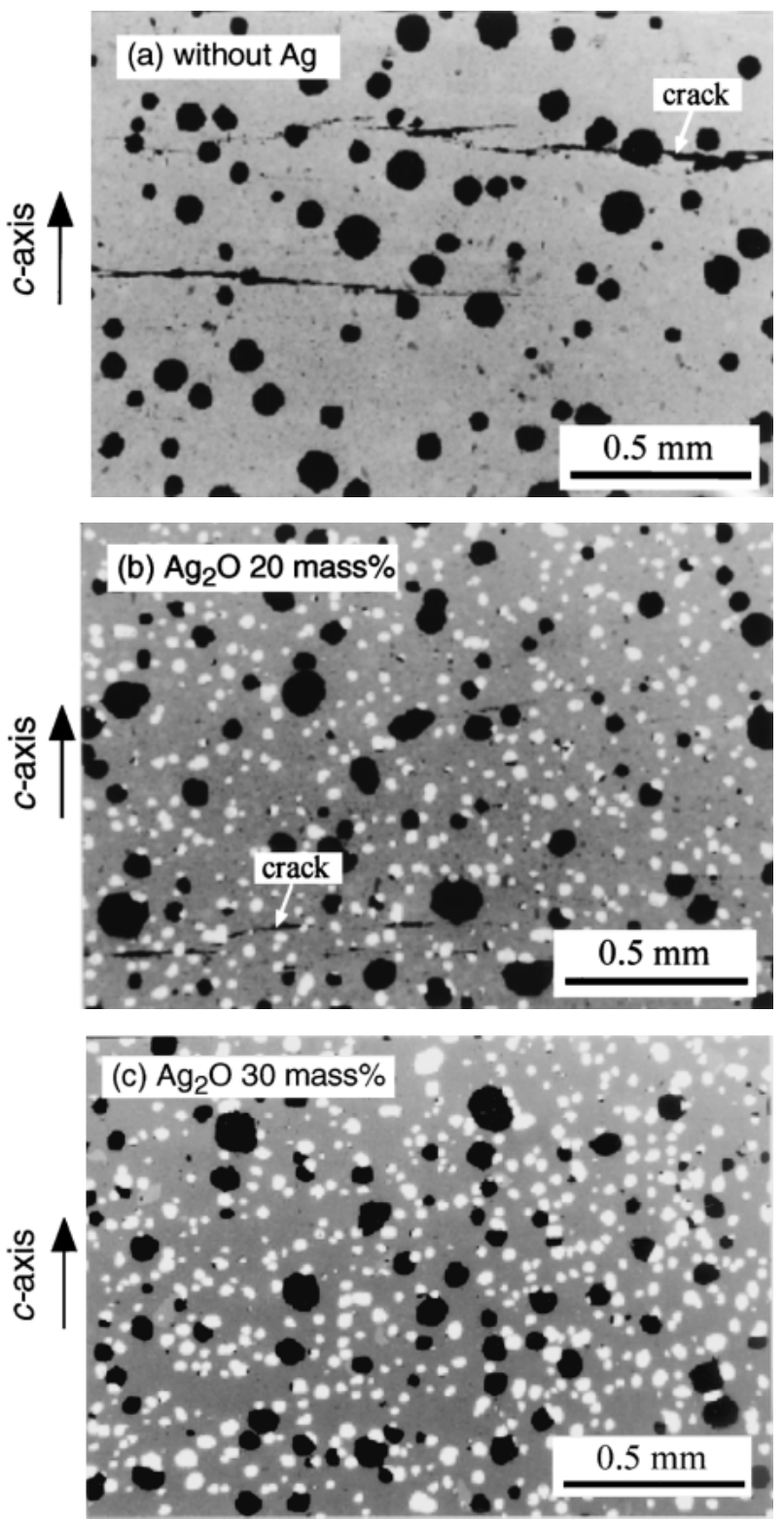

Fig. 2 Optical micrographs of the polished surfaces of bulk samples: (a) $\mathrm{Ag}$-free; (b) 20 mass $\% \mathrm{Ag}_{2} \mathrm{O}$; and (c) 30 mass $\%$ $\mathrm{Ag}_{2} \mathrm{O}$.

Fig. 2 にバルク体の光学顕微鏡写真を示す. Fig. 2(b), (c)にみられる白い粒子は $\mathrm{Ag}_{2} \mathrm{O}$ から生成した $\mathrm{Ag}$ 粒子であ り, 黒い部分はボイドを示している. Ag 粒子は直径 $10 \sim 30$ $\mu \mathrm{m}$ の球状粒子としてバルク体中に均一に分布して抢り, $\mathrm{Ag}_{2} \mathrm{O}$ 添加量による形状, 粒径の大きな変化は見られなかっ た. 次にクラックの状態に着目すると, $\mathrm{Ag}$ が無添加の試料 では Fig. $2(\mathrm{a})$ に見られるように $a-b$ 面内にマクロクラック が多数存在するのが観察された. このようなクラックの発生 は, 降温時における熱応力の発生, 211 粒子と 123 マトリッ クス相との熱膨張係数の違いによる応力の発生, および酸素 アニールによる正方晶から斜方晶への転移により発生する応 力などが原因と考えられている25)。Fig. 2(b)，(c)に見られ るように, クラックの数, 長さは, $\mathrm{Ag}$ を添加した試料では 著しく減少しており, 特に $\mathrm{Ag}_{2} \mathrm{O}$ を 30 mass\%添加した試料 ではクラックを観察することができなかった.

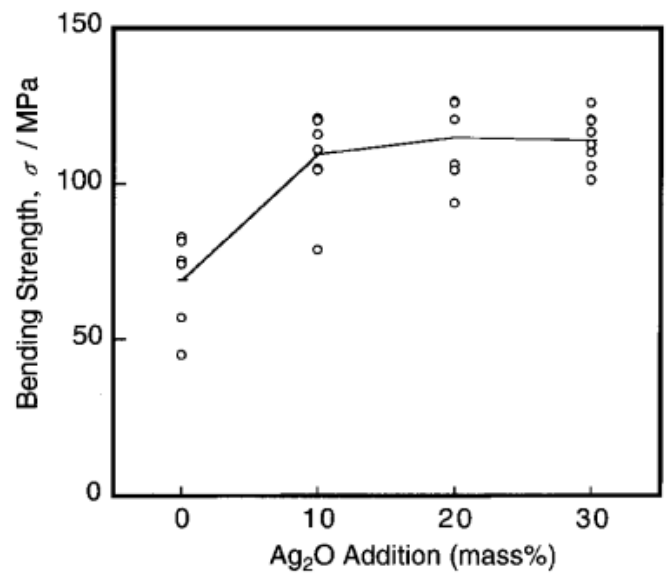

Fig. 3 Relationship between the three-point bending strength measured at room temperature and the amount of $\mathrm{Ag}_{2} \mathrm{O}$ addition.

\section{2 機械的強度評価}

Fig. 3 に室温における 3 点曲げ強度の全測定結果を $\mathrm{Ag}$ 添 加量に対してプロットした結果を示す. $\mathrm{Ag}$ 無添加試料の曲

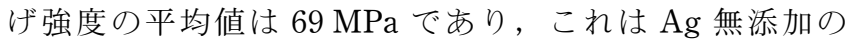
$\mathrm{Y} 123$ バルク体の室温に打ける曲げ強度の報告值 $(56$ $\left.\mathrm{MPa}^{26)}\right)$ とほぼ同程度の值である。曲げ強度の值は $\mathrm{Ag}$ の添 加により大きく改善され, 平均值は $110 \sim 115 \mathrm{MPa}$ に達し た．また，各バルク体の曲げ強度の最低值も $\mathrm{Ag}$ の添加量の 増大につれて向上しており， $\mathrm{Ag}$ 添加によるクラックの減少 が，バルク体の機械的強度の改善に大きく寄与していること が分かる。

\section{$3.377 \mathrm{~K}$ における捕捉磁場特性}

Fig. 4 に種々の $\mathrm{Ag}$ 添加量を有するバルク体の $77 \mathrm{~K}$ にお ける捕捉磁場分布を示す．Fig. 4(a)に示すように，Ag 無添 加試料の捕捉磁場分布は単一ピークを示しており，捕捉磁場 の最大值は約 $1.3 \mathrm{~T}$ であった．しかしながら，その分布は完 全な同心円状となっておらず，矢印で示した部分に弱結合に よる捕捉磁場の低下が見られる。これに対し， $\mathrm{Ag}_{2} \mathrm{O}$ を添加 した試料では，ほぼ同心円状の捕捉磁場分布が得られており， $\mathrm{Ag}$ の添加によりクラック等の弱結合が除去されていること が分かる. Ag の添加は捕捉磁場の向上に有効であり, $\mathrm{Ag}_{2} \mathrm{O}$ を 10 20 mass\%まで増やした試料では, 捕捉磁場が 1.8〜2.0 T の非常に高い值に達した。しかしながら， $\mathrm{Ag}_{2} \mathrm{O}$ を 30 mass\%添加した試料の捕捉磁場は $1.1 \mathrm{~T}$ に低下した. Fig. 5 にSQUID を用いて測定した磁化率の温度依存性を, また $77 \mathrm{~K}$ におけるヒステリシスループから Bean モデル27) を用いて計算された $J_{\mathrm{c}}$ の磁場依存性を Fig. 6 に示す. Fig. 5 より, 試料の onset- $T_{\mathrm{c}}$ は約 $93 \mathrm{~K}$ で, 転移温度幅は狭く, 試料による大きな違いは見られなかった。一方, Fig. 6 から 分かるように， $J_{\mathrm{c}}$ の值は各試料により大きく異なっている. 特に $\mathrm{Ag}_{2} \mathrm{O}$ を 30 mass\%添加した試料の $J_{\mathrm{c}}$ は低くなってお り，捕捉磁場が低い原因となっている．Agの過娂添加によ る捕捉磁場の低下は $\mathrm{Sm} 123$ 系や $\mathrm{Nd} 123$ 系などでも報告さ れており18,21)，123 超伝導相の体積割合の低下によるものと 
(a) $\mathrm{Ag}_{2} \mathrm{O}, 0$ mass $\%$

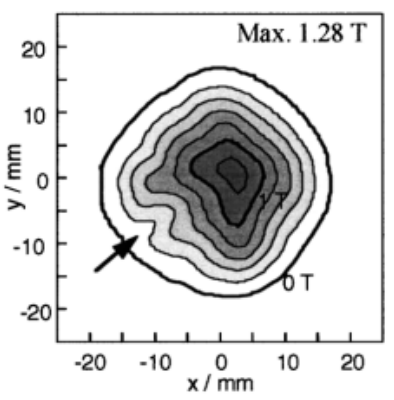

(c) $\mathrm{Ag}_{2} \mathrm{O}, 20$ mass $\%$

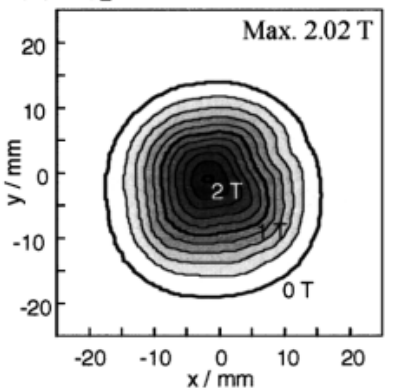

(b) $\mathrm{Ag}_{2} \mathrm{O}, 10$ mass $\%$

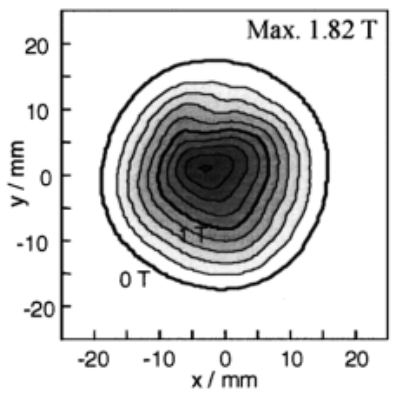

(d) $\mathrm{Ag}_{2} \mathrm{O}, 30$ mass $\%$

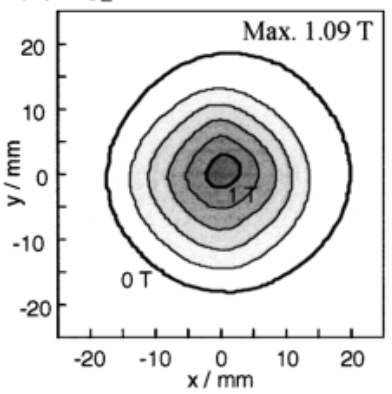

Fig. 4 Trapped field distributions of the $\mathrm{Gd}-\mathrm{Ba}-\mathrm{Cu}-\mathrm{O}$ bulk samples $32 \mathrm{~mm}$ in diameter with various $\mathrm{Ag}$ contents at $77 \mathrm{~K}$. The arrow in the figure (a) indicates the location of the weak link.

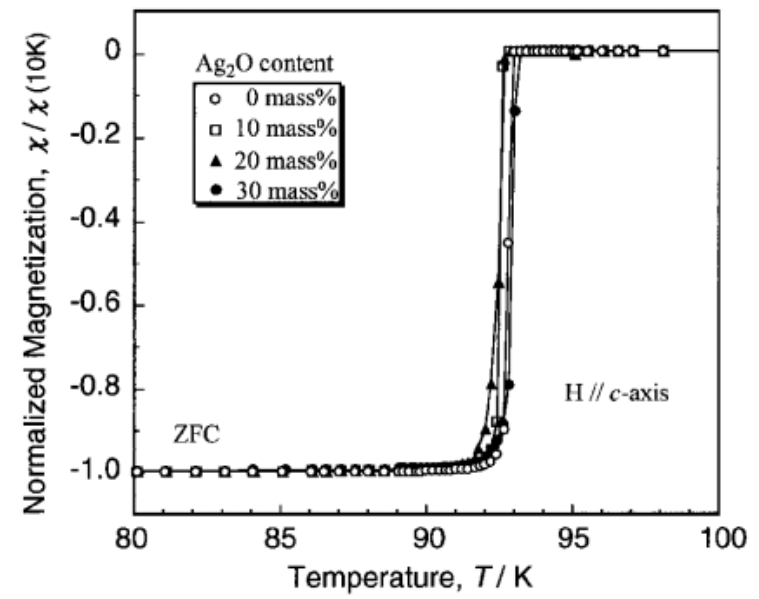

Fig. 5 Temperature dependence of DC-susceptibility for $\mathrm{Gd}-$ $\mathrm{Ba}-\mathrm{Cu}-\mathrm{O}$ specimens with various $\mathrm{Ag}$ contents. The magnetization values were normalized with the value at $10 \mathrm{~K}$.

考えらていれる，ただし，超伝導特性に及ぼす $\mathrm{Ag}$ 添加の影 響については更に詳しい検討が必要と考えられる.

$\mathrm{Y}-\mathrm{Ba}-\mathrm{Cu}-\mathrm{O}$ 系に拈いては，バルク体を液体窒素中で使用 する場合，使用を繰り返すにつれて特性が低下して行くこと が知られて抢り，実用上の障害となっている。これは液体窒 素中での冷却に伴う熱衝撃によりクラックが徐々に進展して いくためと考えられている28-31). そこで, Ag 無添加のバル ク体と $\mathrm{Ag}_{2} \mathrm{O}$ を 10 mass\%添加したバルク体について，1 回 目の捕捉磁場測定後，バルク体に温風を当てて室温に戻し， 再び液体窒素中に直接浸漬することにより急激に冷却した 後, 捕捉磁場測定を行う操作を 5 回繰り返し, 実験回数に よる捕捉磁場の変化を調べた。なお， $\mathrm{Ag}$ 添加したバルク体

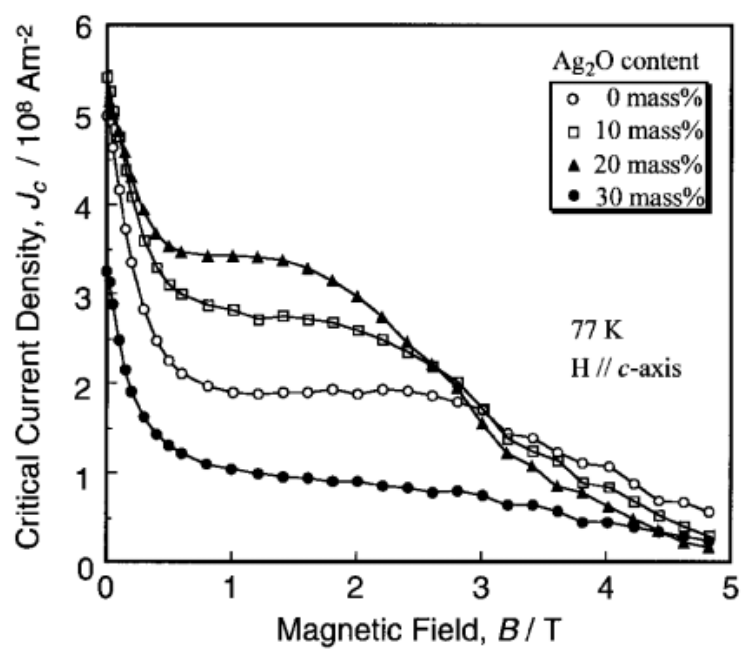

Fig. $6 J_{c}-\mathrm{B}$ curves for $\mathrm{Gd}-\mathrm{Ba}-\mathrm{Cu}-\mathrm{O}$ specimens with various $\mathrm{Ag}$ contents at $77 \mathrm{~K}$.

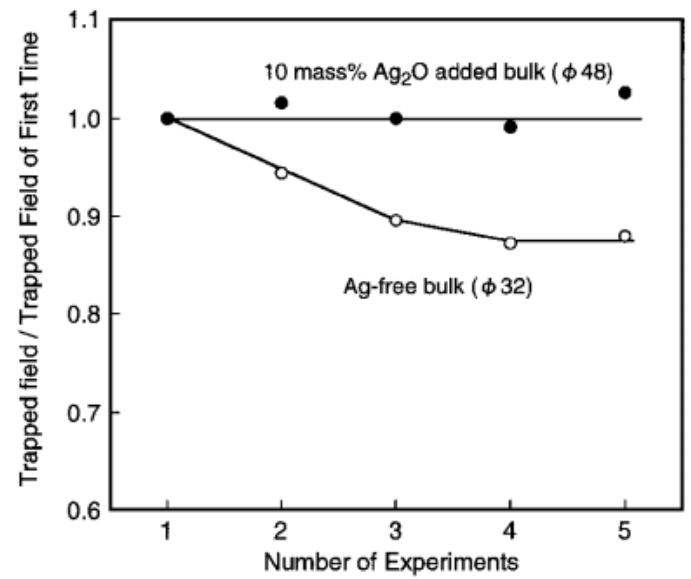

Fig. 7 Relationship between the trapped field at $77 \mathrm{~K}$ for the $\mathrm{Ag}$-free bulk $32 \mathrm{~mm}$ in diameter and the Ag-added bulk $48 \mathrm{~mm}$ in diameter and the number of measurement tests. The values of trapped field were normalized by the initial trapped field values of $1.3 \mathrm{~T}$ for $\mathrm{Ag}$-free bulk and $2.0 \mathrm{~T}$ for $\mathrm{Ag}$-added bulk.

は, 作製後 1 年以上経過した直径 $48 \mathrm{~mm}$ の大型バルク体 (作製直後の捕捉磁場 $2.0 \mathrm{~T}$ ) を使用した. Fig. 7 にバルク体 の捕捉磁場の繰り返し測定の結果を示す. 図中の捕捉磁場は 最初に測定した捕捉磁場の值で規格化した值を示している.

$\mathrm{Ag}$ 無添加のバルク体は測定を繰り返すにつれて特性が低下 したのに対し, Ag を含むバルク体は特性の低下が全く見ら れず，Ag 添加による機械的特性の改善, 熱伝導率の向上が バルク体の特性劣化の抑制に有効に働いていると考えられる.

\section{4 捕捉磁場の温度依存性}

バルク超伝導体の $J_{\mathrm{c}}$ は温度の低下につれて高くなるた め, 液体窒素温度以下では非常に高い磁場を捕捉することが 可能となる. そこで, $\mathrm{Ag}$ 無添加のバルク体と $\mathrm{Ag}_{2} \mathrm{O}$ を 20 mass\%添加したバルク体について, 捕捉磁場の温度依存性 の検討を行った。 なお，バルク体の低温での捕捉磁場測定に おいては，バルク体の電磁力による破壊を抑えるため金属リ ングやエポキシ樹脂による外部補強が一般に行われる 


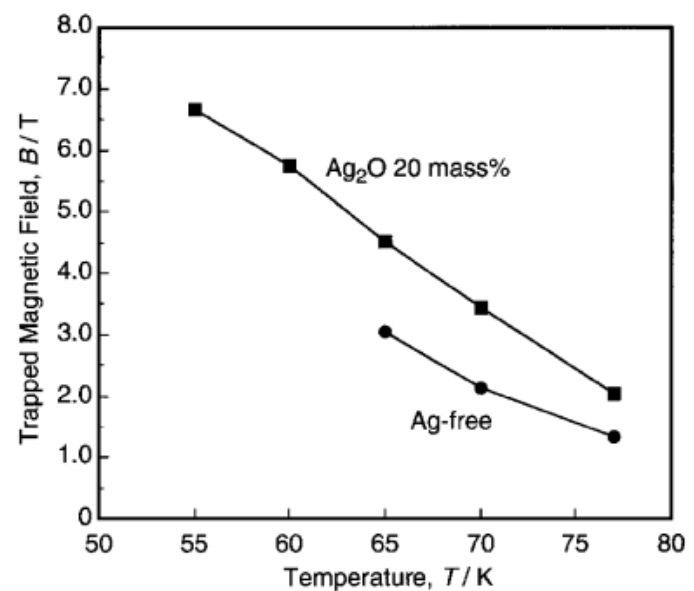

Fig. 8 Temperature dependence of the trapped magnetic field measured on the surface of $\mathrm{Ag}$-free and $\mathrm{Ag}$-added $\mathrm{Gd}-\mathrm{Ba}-\mathrm{Cu}-$ $\mathrm{O}$ bulk samples using Hall sensor. The measurements were performed without reinforcement by the metal ring or resin.

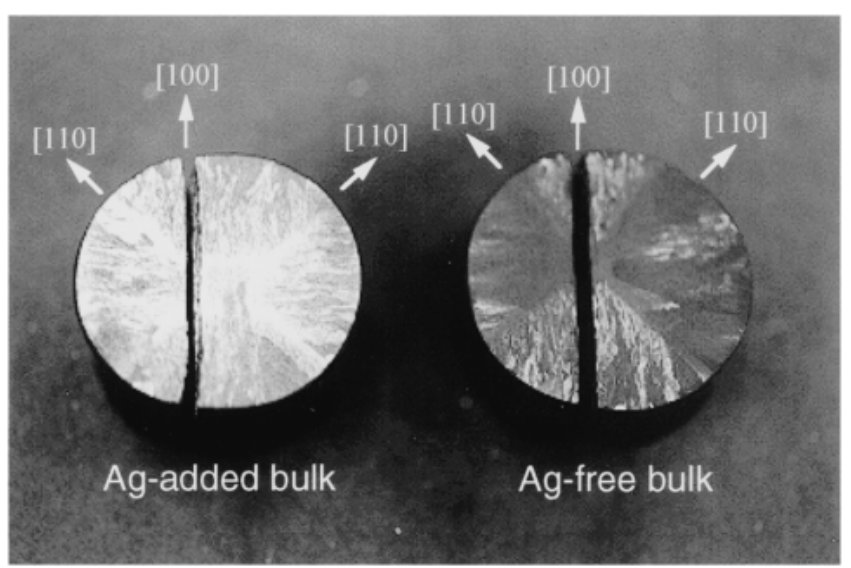

Fig. $9 \mathrm{Gd}-\mathrm{Ba}-\mathrm{Cu}-\mathrm{O}$ bulk samples fractured by the electromagnetic force during the trapped field measurement test.

が2,16-18), 本研究では $\mathrm{Ag}$ 添加の機械的強度への影響を明確 にするため，外部補強を施さないで実験を行った. Fig. 8 に 捕捉磁場の温度依存性を示す. $\mathrm{Ag}$ 無添加の試料の場合, 温 度の低下につれて捕捉磁場は大きくなり， $65 \mathrm{~K} て ゙ 3.0 \mathrm{~T}$ を 捕捉した。しかし， $60 \mathrm{~K}$ に温度を下げて測定したところ， バルク体が破壊した. $\mathrm{Ag}_{2} \mathrm{O}$ を 20 mass\%添加した試料につ いては, $77 \mathrm{~K}$ 同様, 低温に打ける捕捉磁場の值も $\mathrm{Ag}$ 無添 加試料に比べて大きく, $65 \mathrm{~K}$ で $4.5 \mathrm{~T}, 55 \mathrm{~K}$ で $6.7 \mathrm{~T}$ の磁場 を捕捉することができた。しかし，さらに低温での測定では バルク体が破壊した．このように Ag 添加による機械的強度 の向上は強磁場の捕捉に有効であることが分かる.

バルク体の破壊は試料の平均強度よりもむしろ最低強度が 問題となる. Fig. 9 に電磁力によって破壊したバルク体の外 観, Fig. 10 に破断面の写真を示す. 両者のバルク体とも破 壞は[100]方向で生じていることが分かる. Fig. 10 (a)に示 すように, $\mathrm{Ag}$ 無添加試料の破断面に掞いては明瞭なミラー 領域が観察され, 図中に矢印で示した部分が破壊の起点と考 えられる。この部分では 211 相が凝集した領域が観察され ており，211 相と 123 相の熱膨張係数の違いによりクラック

\section{(a) Ag-free sample}

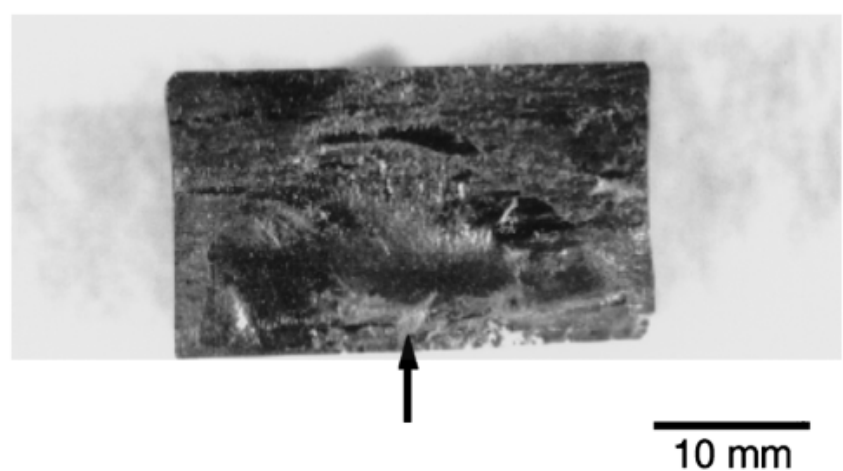

(b) Ag-added sample

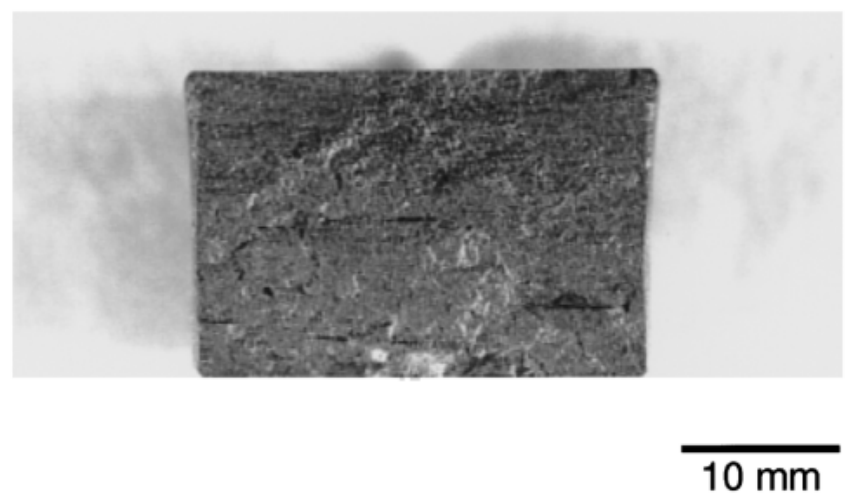

Fig. 10 Photographs showing the fracture surfaces of (a) $\mathrm{Ag}-$ free and (b) $\mathrm{Ag}$-added $\mathrm{Gd}-\mathrm{Ba}-\mathrm{Cu}-\mathrm{O}$ bulk samples fractured by the electromagnetic force. The arrow in figure (a) indicates the estimated site of crack initiation.

が発生したと予想される25). 一方, Fig. 10(b)に示すように, $\mathrm{Ag}$ 添加試料の破断面からは明瞭な破壊の起点は観察できな かった。

\section{4. よ め}

$\mathrm{Ag}_{2} \mathrm{O}$ を 0〜 30 mass\%添加した直径 $32 \mathrm{~mm}$ の $\mathrm{Gd}-\mathrm{Ba}-$ $\mathrm{Cu}-\mathrm{O}$ 系バルク超伝導体を低酸素分圧下で作製し，バルク体 の微細組織, 機械的強度, 捕捉磁場特性に及ぼす $\mathrm{Ag}$ の添加 効果について検討を行った. Ag を添加していないバルク体 の微細組織では $a b$ 面内にマクロクラックが多く見られたが, $\mathrm{Ag}$ の添加によりクラックは著しく減少し, $\mathrm{Ag}_{2} \mathrm{O}$ を 30 mass\%添加した試料ではクラックが観察できなかった．ク ラックの減少に伴い, バルク体の室温における三点曲げ強度 は $\mathrm{Ag}$ 無添加試料の平均值が $69 \mathrm{MPa}$ であったのに対し， $\mathrm{Ag}$ を添加した試料では $110 \sim 115 \mathrm{MPa}$ に大きく改善され た.バルク体の $77 \mathrm{~K}$ に抢ける捕捉磁場は $\mathrm{Ag}_{2} \mathrm{O}$ を 10 20 mass\%添加したときに最大となり，1.8～2.0 T に達した. また，低温における捕捉磁場特性についても検討したところ， $\mathrm{Ag}$ 無添加試料では $65 \mathrm{~K}$ で $3.0 \mathrm{~T}$ の磁場を捕捉した後, さ 
らに低温での測定中，電磁力によりバルク体が破壊した．一 方, $\mathrm{Ag}_{2} \mathrm{O}$ を 20 mass\%添加した試料では， $55 \mathrm{~K}$ で $6.7 \mathrm{~T}$ の 磁場を捕捉することができた．以上のように， $\mathrm{Gd}-\mathrm{Ba}-\mathrm{Cu}-\mathrm{O}$ 系バルク超伝導体に対する Ag の添加はクラックの抑制, 機 械的特性，捕捉磁場特性の改善に非常に有効に作用すること が明らかとなった。

本研究は, 超電導応用基盤技術研究体の研究として, 新工 ネルギー産業技術総合開発機構 (NEDO)の委託を受けて実施 したものである。

文 献

1) S. I. Yoo, N. Sakai, H. Takaichi, T. Higuch and M. Murakami: Appl. Phys Lett. 65 (1994) 633-635.

2) H. Ikuta, A. Mase, Y. Yanagi, M. Yoshikawa, Y. Itoh, T. Oka and U. Mizutani: Supercond. Sci. Technol. 11(1998) 13451347.

3) U. Mizutani, A. Mase, H. Ikuta, Y. Yanagi, M. Yoshikawa, Y. Itoh and T. Oka: Mater. Sci. Eng. B65 (1999) 66-68.

4) S. Nariki, S. J. Seo, N. Sakai and M. Murakami: Supercond. Sci. Technol. 13(2000) 778-784.

5) S. Nariki, N. Sakai and M. Murakami: Physica C 357$\mathbf{3 6 0}(2001)$ 811-813.

6) S. Nariki, N. Sakai and M. Murakami: Physica C 341348(2000) 2409-2412.

7) S. Nariki, N. Sakai and M. Murakami: Physica C 357$360(2001) 629-634$.

8) S. Nariki, N. Sakai and M. Murakami: Proc. MRS2000 Fall Meeting, in press.

9) S. Nariki, N. Sakai and M. Murakami: Advances in Cryogenic Engineering, vol. 47-48 (American Institute of Physics, New York) in press.

10) H. Hinai, S. Nariki, S. J. Seo, N. Sakai, M. Murakami and M. Otsuka: J. Cryogenic Soc. Jpn. 34(1999) 584-588.

11) H. Hinai, S. Nariki, S. J. Seo, N. Sakai, M. Murakami and M. Otsuka: Supercond. Sci. Technol. 13(2000) 676-678

12) S. Nariki, H. Hinai, N. Sakai, M. Murakami and M. Otsuka:
Physica C $\mathbf{3 5 7 - 3 6 0}$ (2001) 817-820.

13) S. Nariki, H. Hinai, N. Sakai, M. Murakami and M. Otsuka: Physica C, in press.

14) Y. Ren, R. Weinstein, J. Liu, R. P. Sawh and C. Foster: Physica C 251 (1995) 15-26.

15) T. Miyamoto, J. Katagiri, K. Nagashima and M. Murakami: Advances in Superconductivity XI, (Springer, Tokyo, 1999) pp. $725-728$

16) P. Schätzle, G. Krabbes, S. Gruss and G. Fuchs: IEEE Trans. Appl. Supercond. 9 (1999) 2022-2025.

17) G. Krabbes, G. Fuchs, P. Schätzle, S. Gruss, J. W. Park, F. Hardinghous, R. Hayn and S. L. Drechsler: Physica C 341348(2000) 2289-2292.

18) H. Ikuta, T. Hosokawa, M. Yoshikawa and U. Mizutani: Supercond. Sci. Technol. 13(2000) 1559-1568.

19) D. Lee and K. Salama: Jpn. J. Appl. Phys. 29(1990) L2017L2019.

20) Y. Nakamura, K. Tachibana, T. Yoshida and H. Fujimoto: J. Japan Inst. Metals 63(1999) 1089-1092.

21) H. Ikuta, A. Mase, U. Mizutani, Y. Yanagi, M. Yoshikawa, Y. Itoh and T. Oka: IEEE Trans. Appl. Supercond. 9(1999) 22192222 .

22) A. Leenders, M. Ullrich and H. C. Freyhardt: IEEE Trans. Appl. Supercond. 9 (1999) 2074-2077.

23) S. Kohayashi, S. Yoshizawa, H. Miyairi, H. Nakane and S. Nagaya: Mater. Sci. Eng. B53(1998) 70-74.

24) M. Muralidhar and M. Murakami: Physica C 357-360(2001) 657-660.

25) F. Yu, K. W. White and R. Meng: Physica C 276(1997) 295308.

26) M. Tomita, T. Kono, Y. Tachi, S. Nariki and M. Murakami: Extended Abstracts of 63th 2000 Fall Meeting of Cryogenic Society of Japan (2000) pp. 187.

27) E. M. Gyorgy, R. B. van Dover, K. A. Jackson, L. F. Schneemeyer and J. V. Waszcazk: Appl. Phys Lett. 55 (1989) 283-285.

28) M. Ullrich, A. Leenders and H. C. Freyhardt: Appl. Phys. Lett. 68(1996) 2735-2737.

29) M. Tomita and M. Murakami: Supercond. Sci. Technol. 13 (2000) 722-724.

30) M. Tomita and M. Murakami: Physica C 341-348(2000) 24432444 .

31) M. Tomita, M. Murakami, K. Sawa and Y. Tachi: Physica C 357-360 (2001) 690-693. 